Jurnal Hukum Mimbar Justitia

Fakultas Hukum Universitas Suryakancana

Vol. 6 No. 2 - Desember 2020, hlm. 153-172.

ISSN: 2477-5681 (Cetak), ISSN: 2580-0906 (Online)

Open Access at: https://jurnal.unsur.ac.id/jmi

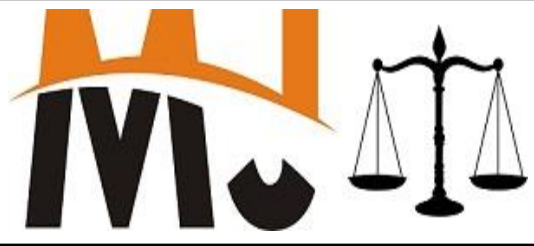

\title{
ANALISIS PUTUSAN GUGATAN PERWAKILAN KELOMPOK SEBAGAI UPAYA MENDAPATKAN MENDAPATKAN JAMINAN PERLINDUNGAN HAK ATAS TANAH (Studi Putusan No. 262.Pdt.G/Class.Action/2016/PN.Jkt.Pst)
}

\author{
Itok Dwi Kurniawan, Azis Akbar Ramadhan, Geby Christabella Randa, \\ Kristiana Widiawati, Septian Joddie Dwianur Sukono \\ Universitas Sebelas Maret, Surakarta \\ Email: itokdwikurniawan@staff.uns.ac.id
}

Masuk: September 2020 Penerimaan: Oktober 2020 Publikasi: Desember 2020

\begin{abstract}
ABSTRAK
Mengkaji lebih dalam mengenai Pengajuan Gugatan perwakilan Kelompok di Indonesia yang diatur di dalam Peraturan Mahkamah Agung No 1 Tahun 2002., dalam analisis ini mengambil salah satu putusan 262.Pdt.G/Class.Action/2016/PN.Jkt.Pst, dalam putusan tersebut berisi tentang sekelompok warga DKI Jakarta Selatan yang terdiri dari beberapa golongan bersama-sama mengajukan gugatan perbuatan melawan Hukum (1365 BW) terhadap instansi terkait yang dinilai telah menimbulkan kerugian materiil dan immateriil akibat tindakan normalisasi Sungai Ciliwung. Penelitian yang dipakai normatif yang bersifat deskriptif dan studi kepustakaan. Dalam kajian ini akan meneliti tentang Pertimbangan Majelis Hakim berkaitan Jaminan Perlindungan Hak Atas Tanah Berdasarkan Undang-Undang Pokok Agraria dan Undang-Undang Pengadaan Tanah. Hasil dari penelitian ini adalah Putusan Hakim tidak mengakomodir Para Penggugat, sehingga aspek keadilan yang hidup di mata masyarkat tidak terpenuhi.
\end{abstract}

Kata Kunci : Gugatan Perwakilan Kelompok, Pertimbangan Hakim, Hak Atas Tanah.

\section{ABSTRACT}

Examine more deeply regarding Class Action Filing in Indonesia which is regulated in the Supreme Court Regulation No.1 of 2002., in this analysis one of the decisions is 262.Pdt.G / Class.Action / 2016 / PN.Jkt.Pst, The decision contains a group of residents of DKI Jakarta Selatan, consisting of several groups, jointly filing a lawsuit against the law (1365 BW) against related agencies which are deemed to have caused material and immaterial losses due to the normalization of the Ciliwung River. The research used is normative descriptive and literature study. In this study will examine the Considerations of the Panel of Judges regarding the Guarantee of Protection of Land Rights based on the Basic Agrarian Law and the Law on Land Acquisition. The result of this research is that the Judge's Decision does not accommodate the Plaintiffs, so that the aspects of justice that live in the eyes of the community are not fulfilled.

Keywords : $\quad$ Lawsuit Group Representatives, Judge's Consideration, Land Rights. 
Jurnal Hukum Mimbar Justitia

Fakultas Hukum Universitas Suryakancana

Vol. 6 No. 2 - Desember 2020, hlm. 153-172.

ISSN: 2477-5681 (Cetak), ISSN: 2580-0906 (Online)

Open Access at: https://jurnal.unsur.ac.id/jmi

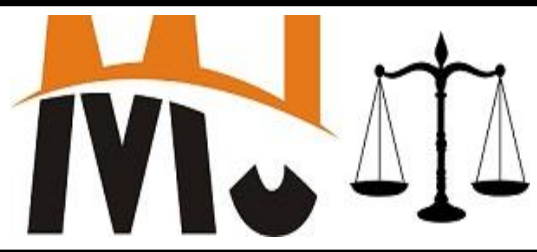

I. PENDAHULUAN

Perkembangan pemenuhan Hak

Asasi Manusia dewasa ini selalu berkembang, dimana setiap manusia mempunyai keinginan untuk mewujudkan dan mepertahankan. Begitupula di negara Indonesia, perwujudan HAM digambarkan sebagai hak konstiutsional yang tercantum didalam Undang-Undang Dasar Negara Republik Indonesia Tahun 1945. Mempertahan hak didalam hukum baik dalam perkara Pidana, Perdata, PTUN, atau perkara lainnya.

Setiap warga negara Indonesia berhak atas pengakuan, jaminan, perlindungan, dan kepastian hukum yang adil serta perlakuan yang sama dihadapan hukum dan ia pun berhak untuk membela haknya apabila ia merasa dirugikan oleh pihak lain. ${ }^{1} \mathrm{Hal}$ ini menjadi dasar pemikiran diadakannya gugatan perdata dalam konteks penyelesaian perkara perdata dalam hukum acara perdata. Secara umum penyelesaian perkara perdata

1 Undang-Undang Dasar Republik Indonesia Tahun 1945, pasal 28D. ada dua macam yaitu penyelesaian yang dilakukan di luar pengadilan dikenal dengan sebutan nonlitigasi, sedangkan penyelesaian perkara perdata yang dilakukan melalui peradilan disebut litigasi. Oleh karena itu, gugatan perdata bisa menjadi dasar diselenggarakannya pengadilan perdata. Gugatan perdata atas pelanggaran hubungan perdata dapat dilakukan dengan dua cara. Pertama, oleh orang yang bersangkutan atau ahli warisnya (gugatan perdata biasa). Kedua, sekelompok orang yang mempunyai kepentingan yang sama (class action). ${ }^{2}$ Gugatan secara class action atau gugatan kelompok telah lama dikenal dan berlaku di negaranegara yang menganut sistem hukum Common Law, seperti Inggris dan negara bekas jajahannya. Di Indonesia, gugatan ini pertama kali diperkenalkan melalui UU No. 23 Tahun 1997 tentang Pengelolaan Lingkungan Hidup. Demi kepastian, ketertiban, dan kelancaran

2 Elise T. Sulistini dan Rudi T. Erwin, 1987, Petunjuk Praktis Menyelesaikan Perkara Perkara Perdata, Bina Aksara, Jakarta, hlm. 20. 


\begin{abstract}
dalam memeriksa, mengadili dan memutuskan gugatan perwakilan kelompok, maka Mahkamah Agung telah mengeluarkan PERMA No. 1 Tahun 2002 tentang Acara Gugatan Perwakilan Kelompok. Oleh karena itu kita coba bahas mengenai gugatan Class Action dikaitkan Jaminan Perlindungan Hak Atas Tanah Berdasarkan Undang-Undang Pokok Agraria dan Undang-Undang Pengadaan Tanah.
\end{abstract}

Itok Dwi Kurniawan, Azis Akbar Ramadhan, Geby Christabella Randa, Kristiana Widiawati, Septian Joddie Dwianur Sukono Jurnal Hukum Mimbar Justitia

Vol. 6 No. 2 - Desember 2020

\section{PEMBAHASAN}

\section{METODE PENELITIAN}

Penelitian yang dilakukan oleh Penulis ini merupakan penelitian normatif yang bersifat deskriptif. Penelitian normatif adalah suatu proses untuk menemukan aturan hukum, prinsip-prinsip hukum, serta doktrindoktrin hukum untuk menjawab isu hukum yang dihadapi. Jenis sumber dan bahan hukum berasal dari bahan hukum primer dan sekunder. Jenis bahan hukum primer yang dipakai adalah Putusan Hakim, bahan hukum seukunder adalah pendapat para ahli hukum. Teknik pengumpulan bahan hukum yang digunakan penulis ialah studi kepustakaan (literature research). Teknik analisis yang digunakan dalam penelitian ini bersifat kualitatif. Sehingga penelitian ini mampu menghasilkan argumentasi serta teori atau konsep baru sebagai cara untuk menyelesaikan masalah yang dihadapi yang dalam hal ini adalah jaminan tentang hak atas tanah.

\section{A. Hukum Acara Perdata, Perkara} Perdata.

Hukum acara perdata ialah hukum yang mengatur bagaimana ditegakannya perdata materiil, dimana hukum acara perdata mengatur bagaimana cara berperkara dipengadilan, bagaimana cara mengajukan gugatan dan lain-lain sebagaimana telah diatur didalam hukum perdata. Menurut Wirjono Prodjodikoro, hukum acara perdata adalah rangkaian peraturan yang memuat cara bagaimana orang harus bertindak dihadapan pengadilan dan cara bagaimana pengadilan itu harus 


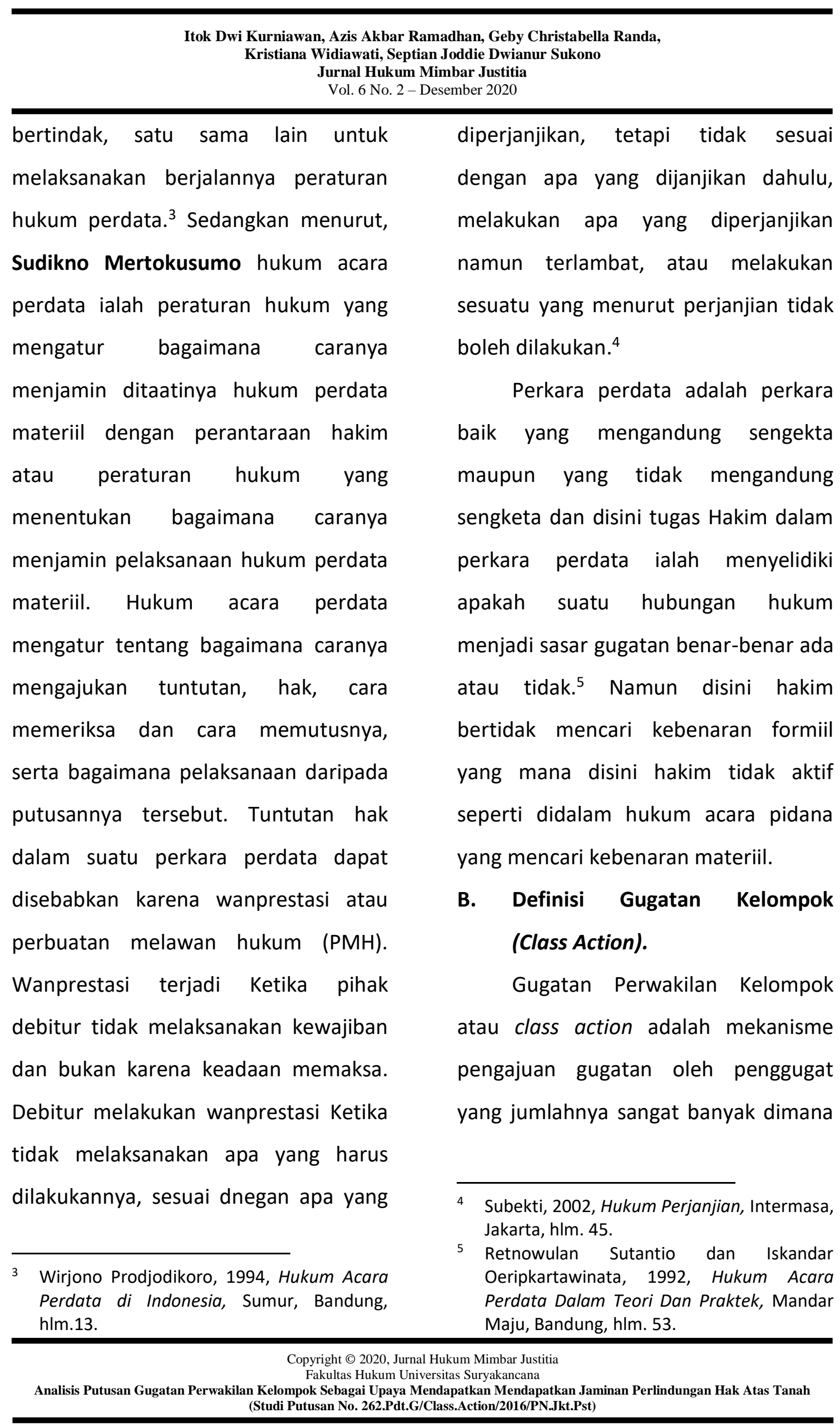


Itok Dwi Kurniawan, Azis Akbar Ramadhan, Geby Christabella Randa,

Kristiana Widiawati, Septian Joddie Dwianur Sukono

Jurnal Hukum Mimbar Justitia

Vol. 6 No. 2 - Desember 2020

gugatan diajukan oleh wakil kelompok, yang mewakili kepentingan sendiri maupun anggota kelompoknya, dengan tuntutan berupa ganti kerugian. Gugatan class action lebih didominasi di negara yang menganut stelsel hukum Anglo Saxon, sementara tradisi hukum di Indonesia lebih dominan dipengaruhi oleh stelsel hukum Eropa Kontinental. ${ }^{6}$ Gugatan class action sendiri diatur didalam beberapa undang-undang yaitu Undang-Undang Nomor 23 Tahun 1997 tentang Lingkungan Hidup, Undang-Undang Nomor 41 tahun 1999 tentang Kehutanan, dan UndangUndang Nomor 8 Tahun 1999 tentang Perlindungan Konsumen. Selain itu diatur pula didalam Peraturan Mahkamah Agung No. 1 Tahun 2002 tentang Acara Gugatan Perwaklan kelompok atau class action adalah suatu tata cara pengajuan gugatan dimana satu orang atau lebih yang mewakili kelompok mengajukan gugatan untuk diri sendiri sekaligus mewakili sekelompok orang yang

6 Emerson Yuntho dan Lembaga Studi dan Advokasi Masyarakat, 2005, Class Action Sebuah Pengantar, Seri Bahan Bacaan Kursus HAM untuk Pengacara $X$. jumlahnya banyak dimana terdapat kesamaan fakta atau dasar hukum antara wakil kelompok dengan kelompok yang dimaksud. Dalam gugatan class action untuk dapat dikabulkan memang harus dijelaskan mengenai legal standing-nya serta kerugian yang dituntut harus jelas dan sama walaupun untuk nominalnya dapat berbeda sesuai dengan kerugianmasing-masing orang per orangnya. Adapun pengertian Class Action secara umum ialah Class Action merupakan sinonim class suit atau representative action yang berarti:

1. Gugatan yang berisi tuntutan melalui proses pengadilan yang diajukan oleh satu atau beberapa orang yang bertindak sebagai wakil kelompok (class representative);

2. Perwakilan kelompok itu bertindak mengajukan gugatan tidak hanya untuk dan atas nama mereka, tetapi sekaligus untuk dan atas nama kelompok yang mereka wakili, tanpa memerlukan 


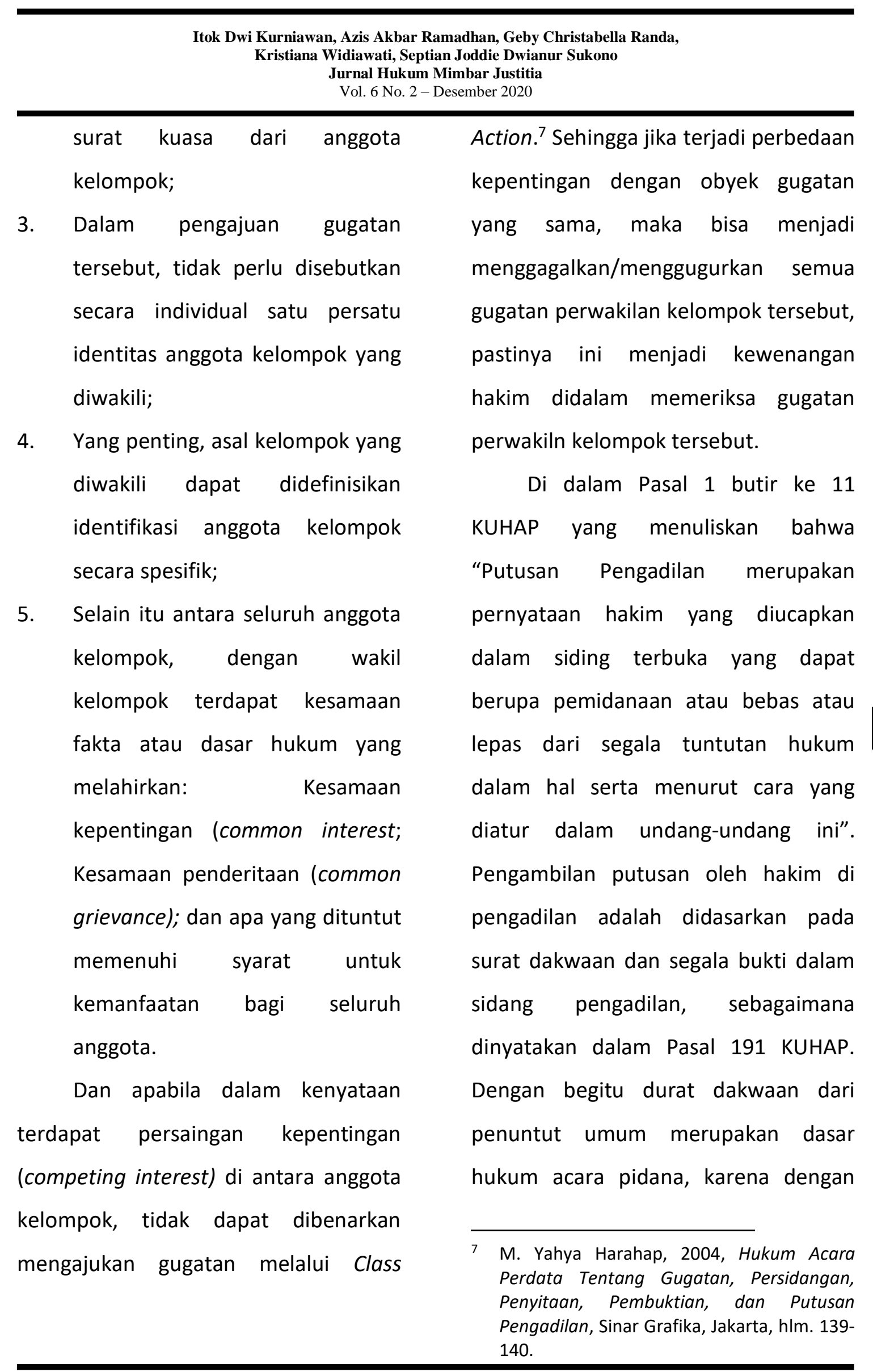




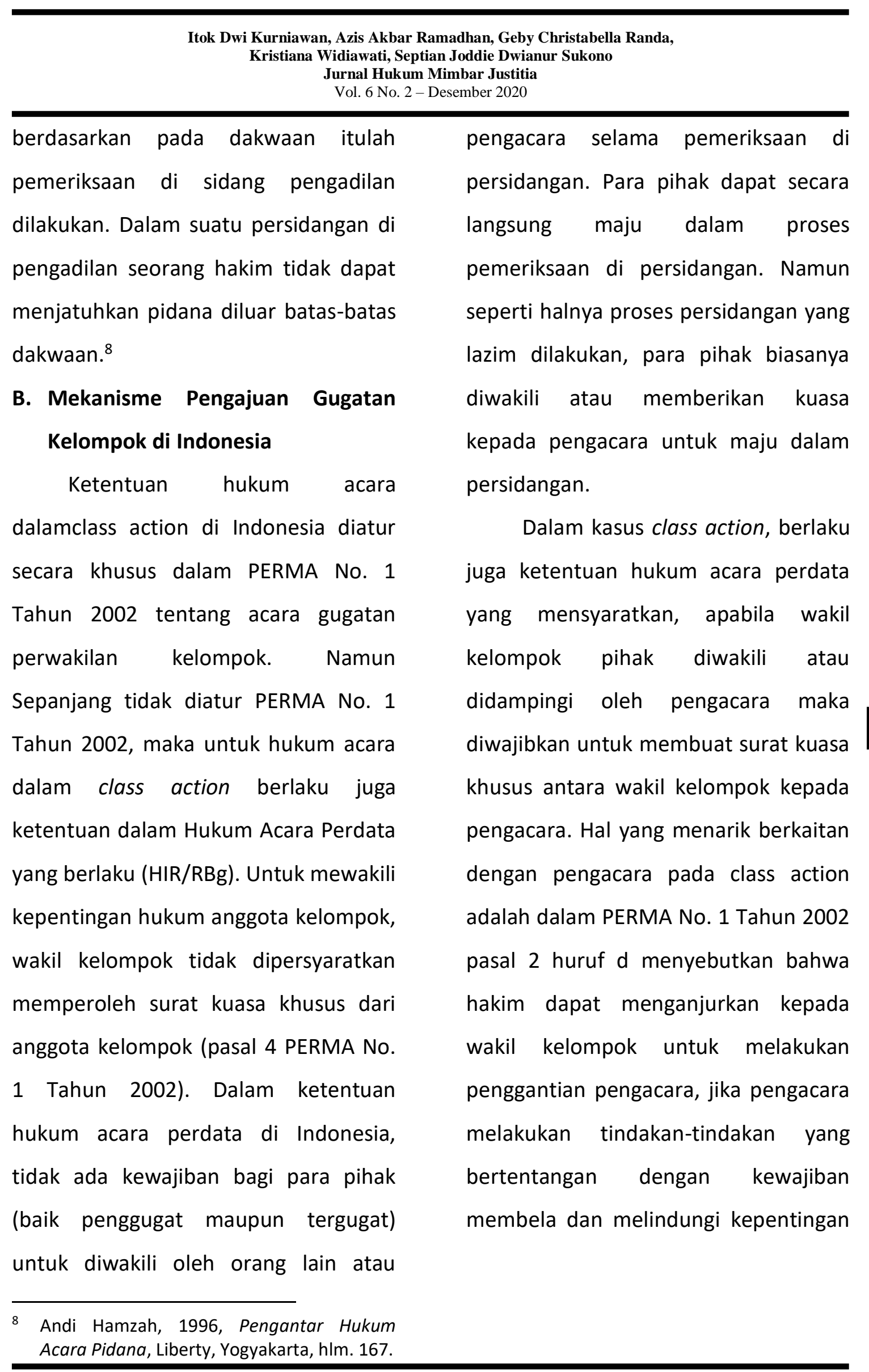




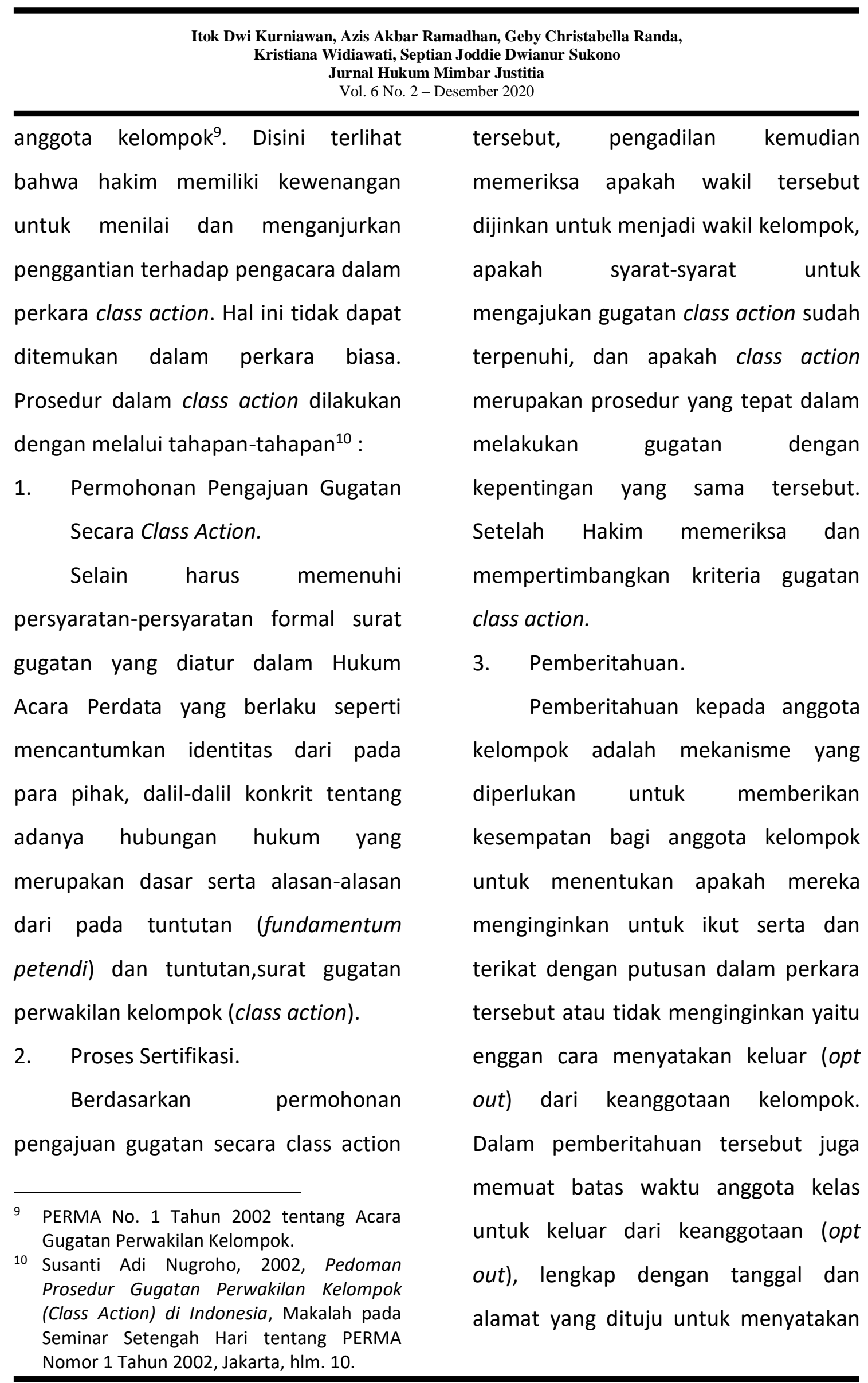


Itok Dwi Kurniawan, Azis Akbar Ramadhan, Geby Christabella Randa,

Kristiana Widiawati, Septian Joddie Dwianur Sukono

Jurnal Hukum Mimbar Justitia

Vol. 6 No. 2 - Desember 2020

opt out. Dengan demikian pihak yang menyatakan keluar dari keanggotaan kelompok tidak terikat dengan putusan dalam perkara tersebut. Menurut pasal 1 huruf PERMA No. 1 Tahun 2002 yang melakukan pemberitahuan kepada anggota kelompok adalah panitera berdasarkan perintah hakim. Cara pemberitahuan kepada anggota kelompok dapat dilakukan melalui media cetak dan atau elektronik, kantor-kantor pemerintah seperti kecamatan, kelurahan atau desa, kantor pengadilan, atau secara langsung kepada anggota yang bersangkutan sepanjang dapat diindentifikasi berdasarkan persetujuan hakim.

Penjelasan tentang jumlah ganti rugi yang akan diajukan. Menurut Mas Acmad Santosa apabila class action tidak menyangkut tuntutan uang (monetary damages) dan hanya mengajukan permintaan deklaratif atau injuction, pemberitahuan (notice) terhadap anggota kelompok (untuk mendapatkan rekonfirmasi) tidak perlu dilakukan ${ }^{11}$. Namun apabila tuntutan menyangkut ganti rugi dalam bentuk uang, pemberitahuan kepada masyarakat atau masing-masing anggota kelompok untuk mengambil sikap (opt in atau opt out) harus disampaikan. Opt in adalah mekanisme dimana anggota kelompok memberikan penegasan bahwa mereka benar-benar merupakan bagian dari class action. PERMA No. 1 Tahun 2002 sendiri hanya mengatur mengenai pemberitahuan dan pernyataaan keluar (opt out), sedangkan mengenai pernyataan yang menyatakan sebagai bagian class action (opt in) tidak diatur. Pada mekanisme pemberitahuan ini membuka kesempatan bagi anggota kelompok untuk menyatakan diri keluar dari class action apabila tidak menghendaki menjadi bagian dari gugatan

4. Pemeriksaan dan Pembuktian dalam class action .

Proses pemeriksaan dan pembuktiaan dalam gugatan class

11 Mas Achmad Santosa, 1997, Konsep dan Penerapan Gugatan Perwakilan Kelompok (Class Action), ICEL, Jakarta, hlm. 20. 
Itok Dwi Kurniawan, Azis Akbar Ramadhan, Geby Christabella Randa,

Kristiana Widiawati, Septian Joddie Dwianur Sukono

Jurnal Hukum Mimbar Justitia

Vol. 6 No. 2 - Desember 2020

action adalah sama seperti dalam perkara perdata pada umumnya.

5. Pelaksanaan Putusan.

Pada dasarnya eksekusi putusan perkara gugatan class action dilakukan atas perintah dan dibawah pimpinan Ketua Pengadilan atas permohonan pihak yang menang seperti diatur dalam hukum acara perdata. Namun mengingat bahwa eksekusi putusan harus dilakukan sesuai dengan amar putusan dalam perkara yang bersangkutan, sedangkan dalam amar putusan gugatan class action yang mengabulkan gugatan ganti kerugian memuat pula perintahagar penggugat melakukan pemberitahuan kepada anggota kelompok, serta perintah pembentukan komisi independen yang komposisi keanggotaannya ditentukan dalam amar putusannya guna membantu kelancaran pendistribusian, maka eksekusi dilakukan setelah diadakannya pemberitahuan kepada anggota kelompok, komisi telah terbentuk, tidak tercapai kesepakatan anatara kedua belah pihak tentang penyelesaian ganti kerugian dan tergugat tidak bersedia secara sukarela melaksanakan putusan. Dalam eksekusi tersebut paket ganti kerugian yang harus dibayar oleh tergugat akan dikelola oleh komisi yang secara administratif dibawah koordinasi panitera pengadilan agar pendistribusian uang ganti kerugian dapat berjalan dengan lancar sesuai dengan besarnya kerugian yang dialami oleh kelompok.

6. Perdamaian.

Dalam gugatan class action dimungkinkan terjadi perdamaian (dading) antara penggugat dengan tergugat. Hakim berkewajiban mendorong para pihak untuk menyelesaikan perkara dimaksud melalui perdamaian, baik pada awal persidangan maupun selama berlangsungnya pemeriksaan perkara (pasal 6 PERMA No. 1 Tahun 2002). Sebelum dilakukan upaya perdamaian dalam class action, pihak penggugat (wakil kelompok) harus mendapatkan persetujuan dari anggota kelompok. Persetujuan ini dapat menggunakan mekanisme pemberitahuan. Umumnya 
Itok Dwi Kurniawan, Azis Akbar Ramadhan, Geby Christabella Randa,

Kristiana Widiawati, Septian Joddie Dwianur Sukono

Jurnal Hukum Mimbar Justitia

Vol. 6 No. 2 - Desember 2020

upaya perdamaian dilakukan di luar proses persidangan. Apabila pihak penggugat (wakil kelompok) dan tergugat sepakat dilakukan perdamaian maka diantara para pihak dilakukan perjanjian perdamaian. Lazimnya perjanjian perdamaian dibuat secara tertulis di atas kertas bermaterai. Berdasarkan perjanjian perdamaian antara kedua belah pihak maka hakim menjatuhkan putusannya lacte van vergelijk) yang isinya menghukum kedua belah pihak mematuhi isi perdamaian yang telah dibuat. Kekuatan putusan perdamaian sama dengan putusan biasa dan dapat dilaksanakan seperti putusan-putusan lainnya. Dalam hal para pihak sepakat melakukan perdamaian maka tidak dimungkinkan upaya banding.

\section{Pertimbangan Majelis Hakim}

Putusan

Nomor

262.Pdt.G/Class.Action/2016/PN .Jkt.Pst Sebagai Upaya Mendapatkan Jaminan

Perlindungan Hak Atas Tanah Berdasarkan Undang-Undang

\section{Pokok Agraria dan Undang-} Undang Pengadaan Tanah.

Negara Hukum adalah konsep yang merupakan produk sejarah. Karena itu unsur-unsur negara hukum mempunyai hubungan yang sangat erat dengan sejarah dan perkembangan masyarakat dari suatu negara. Sementara itu sejarah dan perkembangan masyarakat setiap negara tidaklah sama, sehingga pemaknaan dan unsur-unsur negara hukumnya juga berbeda. Hukum merupakan suatu alat untuk menjalankan sebuah negara melalui kekuasaan. ${ }^{12}$

Henny Nuraeny mengatakan bahwa then one as the deciding factor in holding power is the norm or law. ${ }^{13}$, Tujuan utama negara hukum adalah

12 Dedi Mulyadi dan M. Rendi Aridhayandi, 2015, Putusan Mahkamah Konstitusi Tentang Pemilu Serentak Dihubungkan Dengan Pencegahan Korupsi Politik, Jurnal Hukum Mimbar Justitia, Vol. 1 No.2, Fakultas Hukum Universitas Suryakancana, Cianjur, hlm. 537.

13 Henny Nuraeny \& Tanti Kirana Utami, 2016, The Victim Handling Model of Human Trafficking through Economic Independence, Vol. 16 No. 2, FH-UNSOED, Purwokerto, hlm. 121. 
Itok Dwi Kurniawan, Azis Akbar Ramadhan, Geby Christabella Randa, Kristiana Widiawati, Septian Joddie Dwianur Sukono Jurnal Hukum Mimbar Justitia

Vol. 6 No. 2 - Desember 2020

untuk menyelenggarakan ketertiban. ${ }^{14}$ Hukum yang merupakan sistem peraturan tidak akan tertib jika tanpa dukungan dari masyarakat. Tidak hanya peran lembaga saja.Peraturan tersebut memiliki sistem hukum yang menjadi tatanan di suatu negara. ${ }^{15}$

Dalam Putusan Nomor 262.Pdt.G/Class.Action/2016/PN.Jkt.Pst tidak memberikan jaminan perlindungan hak atas tanah, karena putusan $a$ quo telah bertentangan dengan Buku Kedua Undang-Undang Pokok Agraria Pasal II ayat (1) jo. Undang-Undang Pengadaan Tanah jo. Pasal 24 Peraturan Presiden Nomor 71 Tahun 2012 tentang Penyelenggaraan Pengadaan Tanah Bagi Pembangunan Untuk Kepentingan Umum (Perpres Nomor 71 Tahun 2012). Pertimbangan majelis hakim dalam Putusan Nomor 262.Pdt.G/Class.Action/2016/PN.Jkt.Pst

14 Ahmad Hunaeny dan Tanti Kirana Utami, 2016, Perlindungan Hukum terhadap Pekerja dalam Pelaksanaan Hubungan Industrial, PJIH Volume 3 Nomor 2 Tahun 2016, FH-UNPAD, Bandung, hlm. 407.

15 Dwidja Priyatno dan M. Rendi Aridhayandi, 2016, Resensi Buku (Book Review) Satjipto Rahardjo, 2014, IImu Hukum, PT. Citra Aditya, Bandung, Jurnal Mimbar Justitia Vol. 2 No. 2, Fakultas Hukum Universitas Suryakancana, Cianjur, hlm. 883. tidak tepat dalam menilai bahwa "alatalat bukti yang diajukan oleh para penggugat ternyata tidak ada bukti berupa Sertifikat Hak Milik atas nama para penggugat dan karenanya rumah dan bangunan berdiri di bantaran kali Ciliwung, menurut majelis hakim sudah tepat dilakukan penertiban."

Pertimbangan ini lebih menitikberatkan pada ada tidaknya sertifikat hak atas tanah sebagai tanda bukti hak atas tanah para penggugat. Putusan a quo ini tidak dilandasi oleh dasar hukum yang dapat memperkuat argumentasi majelis hakim banding. Bahkan pertimbangan hukumnya bertentangan dengan Undang-Undang Pokok Agraria, Undang-Undang Pengadaan Tanah dan Pasal 24 Perpres Nomor 71 Tahun 2012. Pertimbangan ini telah mencederai rasa keadilan yang tumbuh dalam masyarakat. Pertimbangan ini tidak memberikan manfaat bagi negara dan masyarakat. Pertimbangan ini telah menimbulkan ketidakpastian dalam hukum pertanahan dan hukum pengadaan tanah bagi kepentingan umum. 
Itok Dwi Kurniawan, Azis Akbar Ramadhan, Geby Christabella Randa,

Kristiana Widiawati, Septian Joddie Dwianur Sukono

Jurnal Hukum Mimbar Justitia

Vol. 6 No. 2 - Desember 2020

Pertimbangan ini tidak melihat pada fakta sosial dan ekonomi para penggugat. Putusan a quo telah keliru dalam menilai objek gugatan. Objek gugatan adalah SP, dan bukan sengketa tanah berdasarkan sertifikat tanah.

Dalam kasus penggusuran paksa untuk pelaksanaan program normalisasi kali Ciliwung menerapkan dua kelompok peraturan perundangundangan yang berbeda. Kluster pertama pemberlakuan Perda Tibum sebagai dasar hukum penerbitan SP 3. Kluster kedua pemberlakuan pembebasan lahan berdasarkan Undang-Undang Pengadaan Tanah dan Perpres Nomor 71 Tahun 2012. Kedua kelompok hukum ini memiliki karakter dan tata cara yang berbeda, maka tidak bisa diterapkan bersamaan dalam satu kasus penggusuran paksa seperti di wilayah Bukit Duri dalam kasus a quo.

$$
\text { Prinsip yang diterapkan dalam }
$$

Perda Tibum adalah penertiban. Penertiban berdasarkan Perda Tibum tidak melihat dasar kepemilikan hak atas tanah warga yang akan ditertibkan. Dalam Perda Tibum,
Pemda Jakarta diberi kewenangan mengadili (yudikatif) secara sepihak dalam menilai apakah warga ini melanggar Perda Tibum atau tidak. Perda Tibum diterapkan karena dianggap oleh Pemda Jakarta ada pelanggaran terhadap pasal-pasal dalam Perda itu. Penertiban berdasarkan Perda Tibum tidak menimbulkan kewajiban hukum pada Pemda Jakarta untuk memberikan ganti rugi terhadap korban penertiban. Karena adanya pelanggaran perda ini, maka Pemda Jakarta mempunyai wewenang secara sepihak untuk melakukan penertiban bagi para pelanggar Perda.

$$
\text { Undang-Undang Pengadaan }
$$

Tanah dan Perpres Nomor 71 Tahun 2012, memiliki tata cara yang sangat berbeda dengan Perda Tibum. Prinsip yang dipegang teguh dalam UndangUndang Pengadaan Tanah adalah kemampuan ekonomi warga terdampak tidak menurun, atau dengan kata lain warga tidak boleh menjadi tidak mampu secara ekonomi ('miskin'). Undang-Undang Pengadaan Tanah dan 


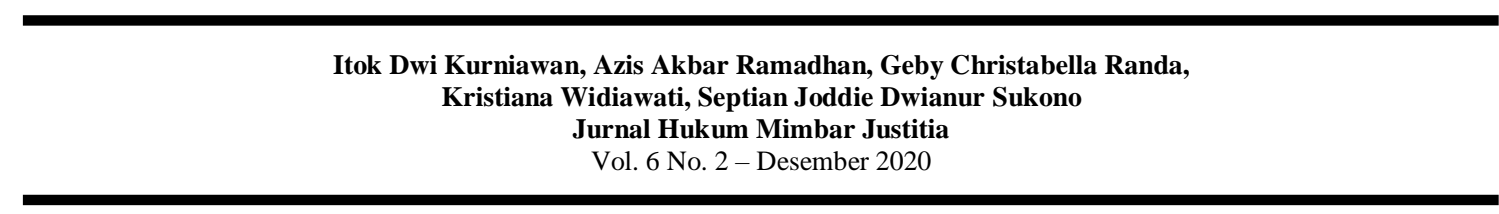

Perpres Nomor 71 Tahun 2012 mengakui kepemilikan tanah para warga baik de jure maupun de facto.

Penjelasan Pasal 40 UndangUndang Pengadaan Tanah jo. Pasal 17 ayat (2) Perpres Nomor 71 Tahun 2012 membuat beberapa kriteria para pemegang hak atas tanah yang berhak mendapatkan penggantian yang layak adalah: (1) pemegang hak atas tanah; (2) pemegang hak pengelolaan; (3) nazir, untuk tanah wakaf; (4) pemilik tanah bekas milik adat; (5) masyarakat hukum adat; (6) pihak yang menguasai tanah negara dengan iktikad baik; (7) pemegang dasar penguasaan atas tanah; dan/atau (8) pemilik bangunan, tanaman, atau benda lain yang berkaitan dengan tanah.

Para pemilik tanah dengan status tanah bekas milik adat (tidak bersertifikat) diakui oleh peraturan perundang-undangan pengadaan tanah jo. Undang-Undang Nomor 5 Tahun 1960 tentang Peraturan Dasar PokokPokok Agraria (Buku Kedua, KetentuanKetentuan tentang Konversi, Pasal II ayat (1)). Bukti kepemilikan atas tanah bekas milik adat yang diakui adalah: “(1) petuk pajak bumi/landrente, girik, pipil, ketitir, verponding Indonesia atau alat pembuktian tertulis dengan nama lainnya, sebagaimana diatur dalam Pasal II, VI, dan VII Ketentuan Konversi Undang-Undang Pokok Agraria; (2) akta pemindahan hak yang dibuat di bawah tangan yang dibubuhi tanda kesaksian oleh kepala adat, lurah, kepala desa atau nama lain yang dibuat sebelum berlakunya Peraturan Pemerintah Nomor 10 Tahun 1961 tentang Pendaftaran Tanah dengan disertai alas hak yang dialihkan; (3) surat tanda bukti hak milik yang diterbitkan berdasarkan Peraturan Swapraja yang bersangkutan; (4) surat keputusan pemberian hak milik dari pejabat yang berwenang baik sebelum atau sejak berlakunya Undang-Undang Pokok Agraria; (5) surat keterangan riwayat tanah yang pernah dibuat oleh Kantor Pelayanan Pajak Bumi dan Bangunan disertai dengan alas hak yang dialihkan" (Pasal 21 ayat (2) huruf a, b, c, d, dan e Perpres Nomor 71 Tahun 2012). 


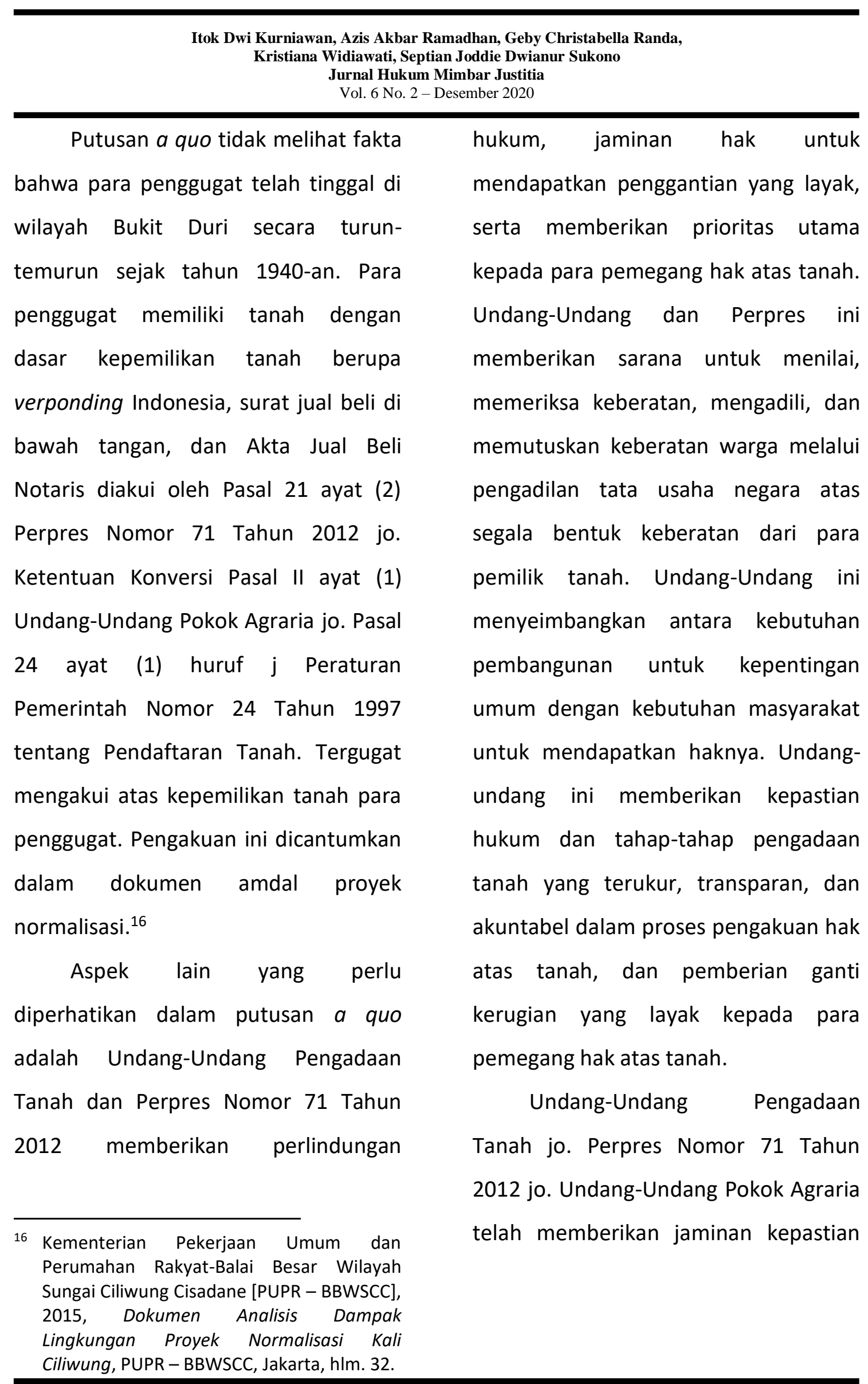


Itok Dwi Kurniawan, Azis Akbar Ramadhan, Geby Christabella Randa,

Kristiana Widiawati, Septian Joddie Dwianur Sukono

Jurnal Hukum Mimbar Justitia

Vol. 6 No. 2 - Desember 2020

hukum bagi para penggugat. ${ }^{17}$ Putusan

a quo yang mengatakan bahwa para penggugat tidak ada yang memiliki sertifikat hak milik atas tanah telah melanggar prinsip asas kepastian hukum dan asas legalitas. Status tanah tidak bersertifikat tetap dilindungi oleh Undang-Undang Pokok Agraria, Undang-Undang Pengadaan Tanah, dan Perpres Nomor 71 Tahun 2012. Tanahtanah para penggugat yang tidak bersertifikat tetap mempunyai hak untuk mendapatkan penggantian yang layak.

Putusan a quo telah melanggar prinsip asas kepastian hukum karena pertimbangan majelis hakim banding tidak merujuk pada peraturan perundang-undangan yang berlaku, tidak berdasarkan pada kepatutan yang hidup di dalam masyarakat, dan melanggar prinsip keadilan bagi para penggugat. Kebijakan penggusuran tanpa mengikuti tata cara yang diatur dalam Undang-Undang Pengadaan Tanah dan Perpres Nomor 71 Tahun

17 N. Ismail, 2012, Arah Politik Hukum Pertanahan \& Perlindungan Kepemilikan Tanah Masyarakat, Badan Pembinaan Hukum Nasional, Jakarta, hlm. 51.
2012, jelas melanggar prinsip asas kepastian hukum dan merupakan tindakan inkonstitusional karena Pasal 1 ayat (3) UUD NRI Tahun 1945 jelas menegaskan "negara Indonesia adalah negara hukum."

Kebijakan yang ditetapkan dalam Perda DKI Nomor 1 Tahun 2012 jo. Pergub DKI Nomor 163 Tahun 2012 jo. Kepgub DKI Nomor 2181 Tahun 2014 dan dokumen perencanaan proyek normalisasi kali Ciliwung adalah pengadaan tanah, dilakukan dengan mengacu pada peraturan perundangundangan tentang pengadaan tanah.

Berdasarkan pada kebijakan tersebut di atas, putusan a quo melanggar prinsip asas legalitas. Merujuk pada pendapat Stahl, unsur pertama negara berdasarkan pada hukum adalah terpenuhinya jaminan hak asasi warganya. Melalui putusan $a$ quo jaminan hak para penggugat atas tanah-tanahnya, dan jaminan untuk mendapatkan kompensasi atas tanah dan bangunannya telah dilanggar oleh negara. Negara secara sadar melalui institusi Pengadilan Negeri dan Pemda 


Itok Dwi Kurniawan, Azis Akbar Ramadhan, Geby Christabella Randa,
Kristiana Widiawati, Septian Joddie Dwianur Sukono
Jurnal Hukum Mimbar Justitia
Vol. 6 No. 2-Desember 2020

dengan bersumber pada hukum adalah segala tindakan pemerintah harus

IV. PENUTUP

berdasarkan pada hukum positif, kepatutan yang tumbuh dalam masyarakat, adat-istiadat, dan etika moral. Kebijakan pelaksanaan program ini harus berdasarkan pada peraturan pengadaan tanah. Tetapi pelaksanaan kebijakan itu justru bertentangan dengan kebijakan yang telah ditetapkan sebelumnya. Kebijakan penggusuran jelas bertentangan dengan peraturan perundang-undangan pengadaan

A. Kesimpulan.

1. Prosedur dalam class action dilakukan dengan melalui tahapan-tahapan yaitu Permohonan Pengajuan Gugatan Secara Class Action yaitu pembuatan gugatan dengan memenuhi persyaratan formal surat gugatan sebagaimana diatur di dalam Hukum Acara Perdata, Proses Sertifikasi diproses ini 


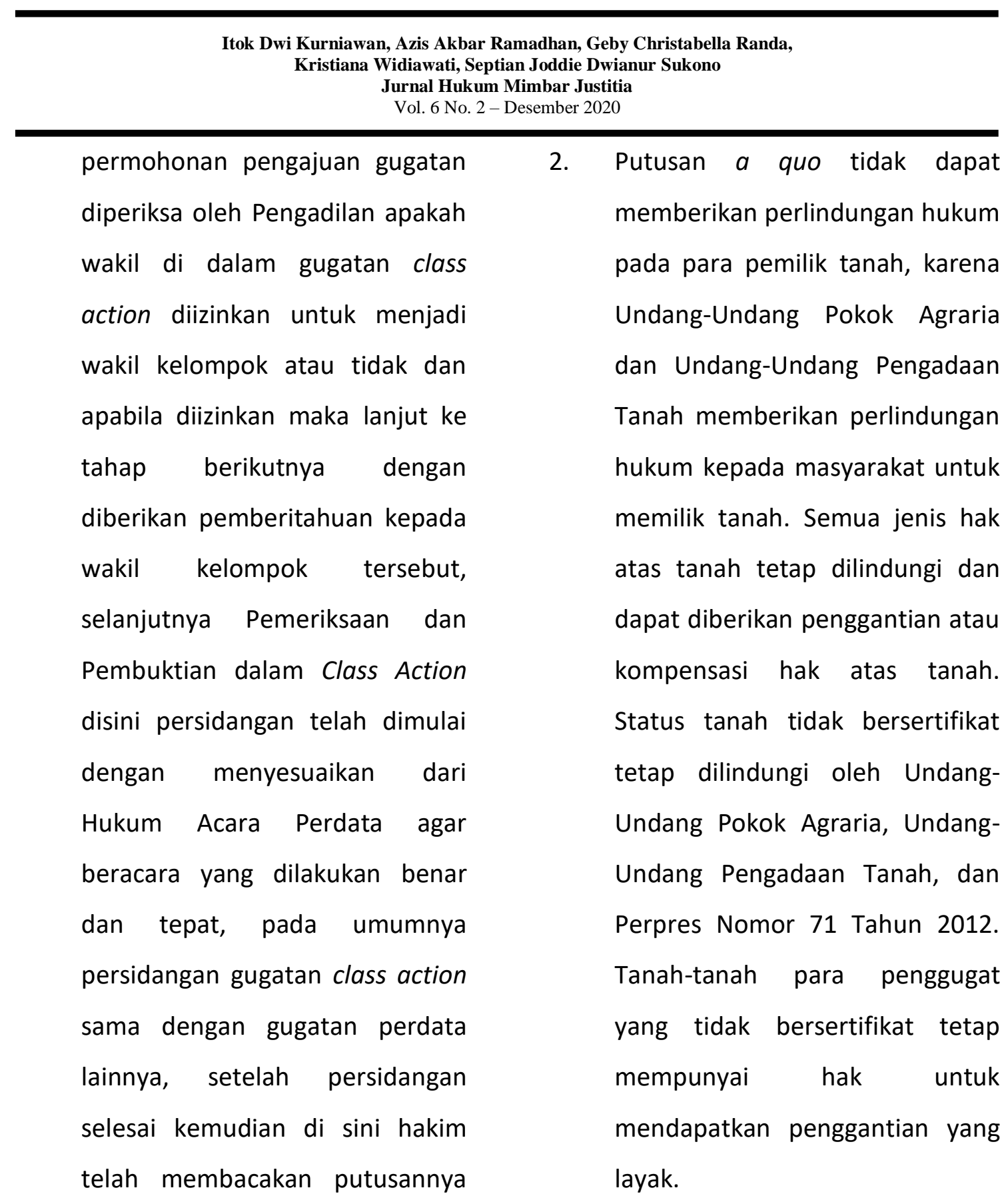

dan putusa tersebut harus segera

dilaksanakan atau dieksekusi, dan

B. Saran.

perlu diperhatikan bahwa di

1. Perlu dilakukan sosialisasi tentang dalam gugatan class action ini dimungkinkan terjadi perdamian antara penggugat dan tergugat ini dikenal dengan istilah dading. Hukum Acara Gugatan Perwakilan Kelompok (Class Action), sehingga masyarakat paham akan 
Itok Dwi Kurniawan, Azis Akbar Ramadhan, Geby Christabella Randa, Kristiana Widiawati, Septian Joddie Dwianur Sukono Jurnal Hukum Mimbar Justitia

Vol. 6 No. 2 - Desember 2020

mekanisme melakukan Gugatan

Perwakilan Kelompok.

2. Pemerintah baik Pusat maupun

Daerah harus memperhatikan

hak-hak rakyat yang menempati

\section{DAFTAR PUSTAKA}

A. Buku.

Andi Hamzah, 1996, Pengantar Hukum Acara Pidana, Liberty, Yogyakarta.

Elise T. Sulistini dan Rudi T. Erwin, 1987, Petunjuk Praktis Menyelesaikan Perkara Perkara Perdata, Bina Aksara, Jakarta.

Emerson Yuntho dan Lembaga Studi dan Advokasi Masyarakat, 2005, Class Action Sebuah Pengantar, Seri Bahan Bacaan Kursus HAM untuk Pengacara $X$.

Kementerian Pekerjaan Umum dan Perumahan Rakyat-Balai Besar Wilayah Sungai Ciliwung Cisadane [PUPR - BBWSCC], 2015, Dokumen Analisis Dampak Lingkungan Proyek Normalisasi Kali Ciliwung, PUPR - BBWSCC, Jakarta.

M. Yahya Harahap, 2004, Hukum Acara Perdata Tentang Gugatan, Persidangan, Penyitaan, Pembuktian, dan Putusan Pengadilan, Sinar Grafika, Jakarta. suatu wilayah yang akan digusur, baik tanah yang bersertifikat maupun tidak bersertifikat sehingga aspek keadilan terpenuhi bagi masyarakat.

Mas Achmad Santosa, 1997, Konsep dan Penerapan Gugatan Perwakilan Kelompok (Class Action), ICEL, Jakarta.

N. Ismail, 2012, Arah Politik Hukum Pertanahan \& Perlindungan Kepemilikan Tanah Masyarakat, Badan Pembinaan Hukum Nasional, Jakarta.

Retnowulan Sutantio dan Iskandar Oeripkartawinata, 1992, Hukum Acara Perdata Dalam Teori Dan Praktek, Mandar Maju, Bandung.

Subekti, 2002, Hukum Perjanjian, Intermasa, Jakarta.

Susanti Adi Nugroho, 2002, Pedoman Prosedur Gugatan Perwakilan Kelompok (Class Action) di Indonesia, Makalah pada Seminar Setengah Hari tentang PERMA Nomor 1 Tahun 2002, Jakarta.

Wirjono Prodjodikoro, 1994, Hukum Acara Perdata di Indonesia, Sumur, Bandung.

B. Peraturan Perundang-Undangan. Undang-Undang Dasar Negara Republik Indonesia Tahun 1945. 
Itok Dwi Kurniawan, Azis Akbar Ramadhan, Geby Christabella Randa, Kristiana Widiawati, Septian Joddie Dwianur Sukono Jurnal Hukum Mimbar Justitia

Vol. 6 No. 2 - Desember 2020

Undang-Undang Nomor 5 Tahun 1960

Tentang Peraturan Dasar Pokok-Pokok Agraria

Undang-Undang Nomor 23 Tahun 1997 tentang Lingkungan Hidup.

Undang-Undang Nomor 8 Tahun 1999 tentang Perlindungan Konsumen.

Undang-Undang Nomor 41 tahun 1999 tentang Kehutanan.

Undang-Undang Nomor 2 Tahun 2012 Tentang Pengadaan Tanah Bagi Pembangunan Untuk Kepentingan Umum

Peraturan Presiden Nomor 71 Tahun 2012 Tentang

Penyelenggaraan Pengadaan Tanah Bagi

C. Jurnal.

Ahmad Hunaeny dan Tanti Kirana Utami, 2016, Perlindungan Hukum terhadap Pekerja dalam Pelaksanaan Hubungan Industrial, PJIH Volume 3 Nomor 2 Tahun 2016, FH-UNPAD, Bandung.

Dedi Mulyadi dan M. Rendi Aridhayandi, 2015, Putusan Mahkamah Konstitusi Tentang Pemilu Serentak Dihubungkan Dengan Pencegahan Korupsi Politik, Jurnal Hukum Mimbar Justitia, Vol. 1 No.2, Fakultas Hukum Universitas Suryakancana.
Pembangunan Untuk

Kepentingan Umum

Peraturan Daerah Provinsi Daerah Khusus Ibukota Jakarta

Nomor 1 Tahun 2012

Tentang Rencana Tata

Ruang Wilayah 2030

Peraturan Gubernur DKI Nomor 163

Tahun 2012 Penguasaan Perencanaan/ Peruntukan Bidang Tanah Bagi Pelaksanaan Pembangunan Untuk Kepentingan Umum Rencana Trace Kali Ciliwung Dari Pintu Air ManggaraiKampung Melayu

Peraturan Mahkamah Agung No. 1 Tahun 2002 tentang Acara Gugatan Perwakilan Kelompok atau class action.

Dwidja Priyatno dan M. Rendi Aridhayandi, 2016, Resensi Buku (Book Review) Satjipto Rahardjo, 2014, Ilmu Hukum, PT. Citra Aditya, Bandung, Jurnal Mimbar Justitia Vol. 2 No. 2, Fakultas Hukum Universitas Suryakancana, Cianjur.

Henny Nuraeny \& Tanti Kirana Utami, 2016, The Victim Handling Model of Human Trafficking through Economic Independence, Vol. 16 No. 2, FH-UNSOED, Purwokerto. 